\title{
PROBLEMATIKA PEMANFAATAN BUKU PAKET PENDIDIKAN AGAMA ISLAM SEKOLAH DASAR DI KOTA BALIKPAPAN
}

\author{
PROBLEMS IN UTILIZING ELEMENTARY \\ SCHOOL ISLAMIC RELIGION EDUCATION \\ TEXTBOOKS IN BALIKPAPAN CITY
}

\author{
Abu Muslim \\ Balai Litbang Agama Makassar \\ Jl. AP. Pettarani No. 72 Makassar 90222 \\ Email: abumuslim.litbang@gmail.com
}

Naskah diterima 15 Maret 2016, direvisi 17 April 2016, disetujui 20 Juli 2016

\begin{abstract}
This research is aimed at acknowledging the effectiveness of utilizing elementary school Islamic Religion Education Textbooks in Balikpapan City. The focus of this research in the availability and utilization of as well as the problems faced in relation to the books. This research uses descriptive qualitative method. Data Collection was performed though interviews and observations. The collected data were then sorted based on research focus category for further in-depth analysis. The research results show that in Balikpapan city, the optimization of the utilization of Islamic Religion Education Books in Elementary Schools highly depends on the availability of compulsory and auxiliary books as the manifestation of the policies issued by the entire education apparatus, starting from stakeholders, education components, as well as public support. Curriculum selection also greatly affects the book utilization process. Because, in fact, the 2013 curriculum book distribution is not yet maximum. There is even a school deciding to return to the Education Unit Level Curriculum due to textbook availability, whereas the schools concerned is one of the pilot schools for the implementation of the 2013 curriculum in Balikpapan City. The aspect of supervision on distribution also becomes important in the context of supporting the achievement of the Islam religion education objective through the requirement-based book availability. However, in general, teachers and parents' initiatives greatly support the maximization of the utilization of books as learning sources in Balikpapan City.
\end{abstract}

Keywords: Balikpapan, package books, Islamic Religion Education, Elementary School

\section{Abstrak}

Penelitian ini bertujuan untuk mengetahui efektifitas pemanfaatan buku ajar Pendidikan Agama Islam (PAI) sekolah dasar di Kota Balikpapan. Fokus penelitiannya adalah seputar ketersedian, pemanfaatan dan problem yang dihadapai berkenaan dengan buku tersebut. Penelitian ini menggunakan metode kualitatif deskriptif. Pengumpulan data dilakukan dengan melakukan wawancara dan observasi. Data yang telah terkumpul kemudian dipilah-pilah menurut kategori fokus penelitian untuk kemudian dianalisa secara mendalam. Hasil penelitian menunjukkan bahwa di kota Balikpapan optimalisasi pemanfaatan buku PAI di Sekolah Dasar (SD) sangat bergantung pada ketersediaan buku wajib dan penunjang sebagai manifestasi kebijakan yang dikeluarkan oleh seluruh perangkat pendidikan, mulai dari stakeholder, komponen pendidikan, serta dukungan masyarakat. Pemilihan kurikulum juga sangat mempengaruhi proses pemanfaatan buku. Sebab, faktanya, penyaluran dan distribusi buku kurikulum 2013 belum maksimal, bahkan terdapat sekolah yang memutuskan untuk kembali ke Kurikulum Tingkat Satuan Pendidikan (KTSP) karena alasan ketersediaan buku paket. Padahal sekolah tersebut adalah salah satu sekolah percontohan untuk implementasi kurikulum 2013 di Kota Balikpapan. Aspek pengawasan terhadap distribusi juga menjadi penting dalam rangka menopang pencapaian tujuan pendidikan agama Islam melalui kesesuaian buku berbasis kebutuhan. Secara umum dapat disimpulkan bahwa inisiatif guru dan orangtua murid sangat menunjang maksimalisasi pemanfaatan buku sebagai sumber belajar di Kota Balikpapan.

Kata kunci: Balikpapan, buku paket, Pendidikan Agama Islam, Sekolah Dasar 


\section{PENDAHULUAN}

Pendidikan Agama Islam di Seklah Dasar (SD)/Madrasah Ibtidaiyah (MI) bertujuan untuk menumbuhkembangkan akidah, dan mewujudkan manusia Indonesia yang taat beragama dan berakhlak mulia. ${ }^{1}$ Oleh karena itu, pengembangan dan pemanfaatan semua aspek yang berkaitan dengan PAI sudah semestinya dilakukan. Hal ini dapat dipahami dari UU Sisdiknas No. 20 Tahun 2003 dan PP No. 32 Tahun 2013, sebagai perubahan atas PP. No. 19 Tahun 2005 tentang Standar Nasional Pendidikan (SNP), Permendiknas No. 22 Tahun 2006 tentang Standar Isi, Permendiknas No. 23 Tahun 2006 tentang Standar Kompetensi Lulusan, dan Permendiknas No. 24 Tahun 2006 tentang pelaksanaan Permendiknas No. 22 dan $23 .^{2}$

Salahsatukelemahan prosespelaksanaan Pendidikan Agama Islam di sekolah adalah keterbatasan sarana/prasarana, sehingga pengelolaannya cenderung seadanya. Pendidikan agama yang dianggap sebagai salah satu aspek penting dalam pendidikan seringkali kurang diberi prioritas dalam urusan fasilitas. Selain itu, metode pengajaran PAI juga kurang mendorong penjiwaaan terhadap nilai-nilai keagamaan. Buku paket pendidikan agama juga belum memadai untuk membangun kesadaran beragama, memberikan keterampilan fungsional keagamaan, dan mendorong

${ }^{1}$ Badan Standar Nasional Pendidikan. 2006. Standar Isi untuk Satuan Pendidikan Dasar dan Menengah. Jakarta, Badan Standar Nasional Pendidikan, h. 57-59.

${ }^{2}$ Ahmad Nur S. 2011. Pengembangan Kurikulum Pendidikan Agama Islam (PAI) di Sekolah Menengah Atas (SMA) (Studi Multikasus di SMA Negeri 2 Lumajang dan SMA Jendral Sudirman Lumajang). Tesis Pada Konsentrasi Pendidikan Agama Islam, Program Pascasarjana UIN Malang. perilaku bermoral dan berakhlak mulia pada peserta didik. ${ }^{3}$ Hasil penelitian Litbang Agama Makassar tentang reformulasi buku paket di madrasah menyebutkan bahwa kurangnya buku penunjang pelajaran PAI di sekolah-sekolah juga menjadi salah satu penyebab kurang maksimalnya sistem transfer pengetahuan dan pengamalan ajaran agama Islam, sebab para guru dan siswa lebih terpaku pada desain yang ditetapkan oleh kurikulum tanpa inisiatif dan kreatifitas untuk mencari bahan bacaan lainnya. Terlebih lagi secara kuantitas ketersediaan buku di perpustakaan sekolah juga sangat terbatas. ${ }^{4} \mathrm{Hal}$ ini juga diperkuat oleh penelitian pengelolaan perpustakaan madrasah yang salah satu poin penting temuannya adalah terbatasnya buku-buku agama dalam koleksi perpustakaan sekolah/ madrasah. ${ }^{5}$

Belajar menggunakan buku adalah suatu perantara yang merupakan sumber pesan belajar yang ingin diteruskan kepada penerima pesan dan memiliki tujuan yang ingin dicapai dalam proses belajar. ${ }^{6}$ Buku teks pelajaran masih dianggap sebagai bahan ajar utama yang mudah digunakan

${ }^{3}$ Atho Mudzhar, Tempo, 24 November 2004,dalam Muhaimin. 2005. Pengembangan Kurikulum Pendidikan Agama Islam di Sekolah, Madrasah, dan Perguruan Tinggi. Jakarta: PT. RajaGrafindo Persada, h. 25-26.

${ }^{4}$ Muhammad As'ad dkk. 2009. Reformulasi BukuBuku Paket Madrasah. Makassar: Idelenggara.

${ }^{5} \mathrm{Abu}$ Muslim. Membaca 'Pusat Literasi' dari Pelosok Negeri (Ironi Pengelolaan Perpustakaan Madrasah Aliyah di Konawe Selatan). PENAMAS Jurnal Penelitian Keagamaan dan Kemasyarakatan Balai Litbang Agama Jakarta, Volume 28 Nomor 1, April-Juni 2015, h. 25-42.

${ }^{6}$ Fauziah Mayusa, "Perbandingan antara Cara Belajar Menggunakan Buku dengan Menggunakan Internet Terhadap Tingkat Konsentrasi Belajar Siswa". Dikutip dari https://www.academia.edu. 
dan mampu mengemas seluruh materi pembelajaran yang akan disajikan. Buku teks pelajaran dapat digunakan sebagai bahan ajar utama maupun sebagai bahan ajar pendukung pembelajaran. Penggunaan buku teks pelajaran dapat disesuaikan dengan kebutuhan pembelajaran itu sendiri. ${ }^{7}$

Dewasa ini banyak sekali buku-buku pelajaran bernuansa pendidikan agama Islam yang dijual di pasaran, sehingga tidak menutup kemungkinan beragam pula kualitas buku yang beredar baik dari segi pengemasan, isi, penyajian materi dan lainlain. Keberagaman ini dapat berimplikasi positif maupun negatif. Implikasi positifnya antara lain: (1) keberagaman menunjukkan kreatifitas dan produktifitas penulis (ini dapat dilihat misalnya dengan banyaknya pengajar yang juga menjadi penulis buku, (2) keberagaman memperkaya khazanah ilmu, (3) keberagaman dapat memacu peningkatan kualitas buku. Buku-buku yang tidak atau kurang berkualitas pasti akan tersingkir, (4) keberagaman dapat merangsang para pemakai buku aktif memberikan penilaian. Sedangkan implikasi negatifnya antara lain: (1) keberagaman buku mempersulit pilihan pengajar untuk memakai buku yang akan diajarkan, (2) di sekolah biasa dilaksanakan UUB (Ulangan Umum Bersama), keberagaman menyebabkan kesulitan pada pembuatan soal dan akhirnya mempersulit testee (pembelajar yang sedang tes atau ujian) ${ }^{8}$

Akan tetapi, pemanfaatan buku PAI sebagai panduan pembelajaran agama

${ }^{7}$ Syaiful Imran, "Fungsi, Tujuan, dan Pemanfaatan Buku Teks dalam Pembelajaran”. Dikutip dari https:// www.ilmupendidikan.net.

${ }^{8}$ Suwarna Pringgawidagda. 2002. Strategi Penguasaan Berbahasa. Yogyakarta: Adicita, h. 141-142.
Islam dalam satuan pendidikan dasar belum maksimal, meskipun jenis dan model buku pelajaran yang beredar di masyarakat sangat melimpah. Belum lagi jika dikaitkan dengan kreatifitas guru dan siswa dalam rangka pemenuhan rasa religiusitas yang membutuhkan buku-buku agama Islam penunjang lainnya sebagai bagian yang tidak terpisahkan dari keterpenuhan pemahaman mendalam, terkait penjelasan-penjelasan tambahan atas materi agama Islam yang tertuang dalam buku wajib PAI yang sudah ada/dianjurkan/diberlakukan.

Berdasar pada latar belakang tersebut, maka dipandang perlu untuk melakukan penelitian lebihlanjutyang dirangkum dalam permasalahan pokok seputar problematika pemanfaatan buku Pendidikan Agama Islam di Sekolah Dasar, meliputi ketersediaan buku teks, mekanisme pemanfaatan buku teks, dan problem yang dihadapi berkenaan dengan buku teks tersebut.

\section{Kajian Teori}

Buku teks adalah buku standar yang disusun oleh pakar dalam bidang itu untuk maksud-maksud dan tujuan instruksional yang dilengkapi dengan sarana-sarana pengajaran yang sesuai dan mudah di pakai oleh pemakainya di sekolah-sekolah dan di perguruan tinggi sehingga dapat menunjang suatu program pengajaran. ${ }^{9}$

Berikut beberapa pemaknaan perihal buku sebagai sumber belajar yang disadur dari berbagai sumber: Association of Educational Communication Technology (AECT) mendefinisikan sumber belajar sebagai

${ }^{9}$ H. G. Tarigan. 1986. Telaah Buku Teks Bahasa Indonesia. Bandung: PT. Angkasa, h. 10. 
semua sumber baik berupa data, orang, atau benda yang dapat digunakan untuk memberi fasilitas(kemudahan) belajar bagi siswa. ${ }^{10}$ Begitupun dengan Mulyasa mengatakan bahwa "sumber belajar dapat dirumuskan sebagai segala sesuatu yang dapat memberikan kemudahan kepada siswa dalam memperoleh sejumlah informasi, pengetahuan, pengalaman dan keterampilan dalam proses belajar mengajar". ${ }^{11}$ Menurut Warsita, sumber belajar adalah semua komponen sistem instruksional baik yang secara khusus dirancang maupun yang menurut sifatnya dapat dipakai atau dimanfaatkan dalam kegiatan pembelajaran. ${ }^{12}$ Menurut Sudjana dan Rivai, sumber belajar adalah suatu daya yang bisa dimanfaatkan guna kepentingan proses belajar mengajar baik secara langsung maupun tidak langsung, sebagian atau keseluruhan. ${ }^{13}$ Pemanfaatan buku teks pelajaran sebagai salah satu sumber belajar dapat memberikan informasi, misalnya definisi suatu konsep, peristiwa tertentu, tempat, dan iklan bahkan data-data lain yang diperlukan. ${ }^{14}$ Lebih lanjut dikemukakan oleh Clark, bahwa pemanfaatan sumber belajar memiliki lima aspek pemanfaatan yakni pemanfaatan teknologi mesin, pemanfaatan tutor, pemanfaatan pengubah perilaku, pemanfaatan pemotivasi belajar,

${ }^{10} \mathrm{~B}$. Warsita. 2008. Teknologi Pembelajaran. Jakarta: PT. Rineka Cipta, h. 209.

${ }^{11}$ E. Mulyasa. 2008. Standar Kompetensi dan Guru Sertifikasi. Bandung: PT. Remaja Rosda Karya, h. 48.

${ }^{12}$ B. Warsita. 2008. Teknologi Pembelajaran. Jakarta: PT. Rineka Cipta, h. 209

${ }^{13}$ Nana Sudjana, dan Ahmad Rivai. 2009. Teknologi Pengajaran. Bandung: Sinar Baru Algesindo, h. 76.

${ }^{14}$ S.J. Yunanto, S.J. 2004. Sumber Belajar Anak Cerdas. Jakarta: PT Grafindo, h. 28. pemanfaatan alat berpikir, dan pemanfaatan pemecahan masalah. ${ }^{15}$

Buku pelajaran atau buku teks terdiri atas buku pelajaran pokok dan buku pelajaran pelengkap. Buku pelajaran pokok disediakan oleh pemerintah. Sedangkan buku pelajaran pelengkap adalah buku-buku terbitan swasta yang dibeli oleh sekolah atau siswa berdasarkan pilihan setempat. Pengertian "setempat" di sini bisa sekolah atau daerah. ${ }^{16}$

\section{METODOLOGI PENELITIAN}

Penelitianiniadalahpenelitiandeskriptif kualitatif dengan melakukan penelusuran problematika pemanfaatan Buku Pelajaran Agama Islam di Sekolah Dasar serta melakukan analisis terhadap hal-hal spesifik dalam penyelenggaraan pendidikan yang menggunakan buku sebagai media belajar, dilanjutkan dengan uraian dan penjelasan komprehensif mengenai berbagai aspek pemanfaatan buku baik individu, kelompok, suatu program, atau suatu situasi sosial. ${ }^{17}$ Penelitian dilaksanakan di Kota Balikpapan, Kalimantan Timur, dengan memilih secara purposive dua Sekolah Dasar Negeri di perkotaan yang terdiri atas satu sekolah yang terkategori sebagai sekolah unggulan/ teladan/favorit/berprestasi, dan satu

${ }^{15}$ Wijaya Kusuma. 2012. Pemanfaatan Sumber Belajar di Sekolah. KTI, tidak diterbitkan, h. 2.

${ }^{16}$ Dedi Supriadi. 2000. Anatomi Buku Sekolah di Indonesia; Problematika Penilaian, Penyebaran, dan Penggunaan Buku Pelajaran, Buku Bacaan dan Buku Sumber. Yogyakarta: Adicita Karya Nusa, h. 1-2.

${ }^{17}$ Deddy Mulyana. 2008. Metodologi Penelitian Kualitatif (Paradigma Baru Ilmu Komunikasi dan Ilmu Sosial Lainnya). Bandung: PT. Remaja Rosdakarya, h. 201. 
sekolah yang tidak terkategori unggulan/ teladan/favorit/berprestasi. Pertimbangan pemilihan dua sekolah dasar negeri itu didasarkan pada tingkatan akreditasi dan prestasi sekolah menurut kebijakan pemerintah setempat, serta pertimbangan rasionalisasi dari peneliti masing-masing dengan metode purposif.

Informan Penelitian terdiri atas informan kunci, informan ahli dan informan biasa. Dalam penelitian ini, informan kunci adalah para guru yang menentukan dan mengajarkan buku-buku PAI di Sekolah Dasar, para siswa terkait. Informan ahli adalah Kepala Sekolah, pemerintah terkait dalam hal ini Kementerian Agama dan Dinas Pendidikan Kota Balikpapan, serta akademisi. Informan biasa dalam penelitian ini adalah mereka yang turut andil dalam penyediaan dan pengawasan buku yakni perangkat ketatausahaan di sekolah yang mengurusi pengadaan dan penyimpanan buku, distributor buku, pengawas, serta orang tua siswa, dan masyarakat umum di lokasi penelitian.

Penelitian ini juga menggunakan metode pengumpulan data observasi dan wawancara. ${ }^{18}$ Salah satu ciri penelitian kualitatif, yang menjadi instrumen adalah peneliti itu sendiri. ${ }^{19}$ Persisnya, analisis dikembangkan dari data yang dikumpulkan selama penelitian, dianalisis pada tingkat reduksi data, disajikan dan dijelaskan secara deskripsi. Artinya bahwa, aktivitas dalam analisis data kualitatif dilakukan secara

\footnotetext{
${ }^{18}$ Cresswell, John W. 1994. Research Design, Qualitative and Quantitative Approaches. California: Thousand Oaks.

${ }^{19}$ Sugiyono. 2010. Metode Penelitian Pendidikan (Pendekatan Kualitatif, Kuantitatif, dan R\&D). Bandung: Alfabeta, h. 305.
}

interaktif dan berlangsung terus-menerus sampai tuntas, sehingga datanya sudah jenuh. ${ }^{20}$

\section{HASIL DAN PEMBAHASAN}

\section{Seputar Pendidikan Dasar Kota Balikpapan}

Balikpapan kota BERIMAN! Sebuah tagline yang mengisyaratkan dominasi agama Islam di ini, sebagai "sambutan hangat" yang membuat penelitian tentang pendidikan agama Islam cukup prospektif. Dari data statistik terakhir (Desember 2014), jumlah penduduk berdasarkan agama di Kota Balikpapan, menunjukkan bahwa kuantitas penduduk beragama Islam menyentuh angka 630.648 jiwa dari 704.371 total penduduk, atau sekitar 89,53 persen. Tentu saja ini adalah angka yang sangat signifikan bagi kota yang memiliki tingkat heterogenitas penduduk yang cukup tinggi (Data base SIAK Disdukcapil Kota Balikpapan, 2014). Potensi ini tentunya merupakan peluang besar pelaksanaan dan pencapaian tujuan pendidikan agama Islam dalam rangka mewujudkan manusia yang bertakwa kepada Allah SWT dan berakhlak mulia, serta bertujuan untuk menghasilkan manusia yang jujur, adil, berbudi pekerti, etis, saling menghargai, disiplin, harmonis dan produktif, baik personal maupun sosial. Tentu saja perwujudannya menghendaki harmoni antara masyarakat Islam dan stakeholder pelaksana pendidikan agama Islam dalam hal ini Kemeterian Agama dan Dinas Pendidikan.

${ }^{20}$ M.B. Miles and Huberman. 1984. Qualitative Data Analysis. London: Sage Publication, 1984). 
Dalam rangka mewujudkan tujuan pendidikan agama Islam, dibutuhkan kerjasama dari semua pihak, baik itu tokoh agama, masyarakat, tokoh pendidikan dan pemerintah. Sejauh ini, menurut Suharto, KASI PAI Kemenag Balikpapan, sudah dilakukan sosialisasi berbagai kebijakan berkenaan dengan pelaksanaan Pendidikan Agama Islam di madrasah dan sekolah umum. Meskipun dalam realitasnya masih terdapat kekurangan di beberapa hal, termasuk di dalamnya implementasi kurikulum PAI yang masih dijumpai beberapa dinamika di lapangan. Khusus di sekolah umum, pelaksanaan PAI memang masih membutuhkan koordinasi aktif antara Kementerian Agama dengan Dinas Pendidikan, sebab fungsi pembinaan guru-guru PAI merupakan kewenangan Kementerian Agama, sementara pada aspek teknis kebijakan sekolah masih selalu harus disesuaikan dengan bangunan kebijakan setiap sekolah sebagai implementasi kebijakan Diknas. Belum lagi soal kuantitas dan kualitas guru PAI yang secara umum masih dibutuhkan peningkatan secara terus menerus. ${ }^{21}$

Data sekolah yang dirilis oleh Dinas Pendidikan dan Kebudayaan Kota Balikpapan menunjukkan bahwa jumlah Sekolah Dasar di Kota Balikpapan sebanyak 174 Sekolah Dasar yang terbagi atas 136 SD Negeri dan 38 SD Swasta yang tersebar di 6 kecamatan. Sementara guru Pendidikan Agama Islam untuk tingkatan Sekolah Dasar menunjukkan jumlah 242 orang, yang terbagi atas 167 PNS, dan 75 Non PNS.

21 Wawancara dengan Suharto, KASI PAI Kemenag Balikpapan.
Tentunya, secara kuantitas setidaknya eksistensi pembelajaran Pendidikan Agama Islam dalam konteks Kota Balikpapan memiliki ruang yang cukup ideal untuk terus berjalan, meskipun secara kualitas tentunya masih harus terus dilakukan pembimbingan. Selanjutnya, penelitian ini memilih secara purpossive dua sekolah yang dijadikan sasaran penelitian yakni SDN 004 Balikpapan Utara yang awalnya merupakan sekolah piloting Kurikulum 2013 yang terletak di pusat kota, namun dengan adanya Permendiknas 160 kemudian beralih kembali ke kurikulum 2006 melalui persetujuan Diknas kota Balikpapan. Sekolah kedua adalah SDN 013 Balikpapan Barat yang terletak di daerah berbukit, mewakili sekolah 'pinggiran kota'.

\section{Ketersediaan Buku Paket PAI}

Secara keseluruhan permasalahan pengadaan buku di Balikpapan tergolong sangat kompleks, karena melibatkan berbagai komponen dalam masyarakat, mulai dari kalangan penerbit, distributor buku, guru, dan birokrasi sekolah, pemerintah daerah dan pusat, serta kalangan lain yang terkait langsung ataupun tidak langsung. Distribusi buku sekolah juga memiliki rantai distribusi yang cukup pelik karena melibatkan banyak pihak. Namun demikian, secara teknis, pengadaan buku pelajaran di Kota Balikpapan tidak ditemukan sebuah prosedur yang tetap dan mutlak, yang bisa dipedomani oleh sekolah, sehingga cenderung mengandalkan inisiatif dari masing-masing sekolah. Pengadaan buku lebih banyak melibatkan secara aktif pihak sekolah dan guru, serta orang tua siswa dalam menginisiasi pengadaan buku 
pelajaran khusunya buku paket Pendidikan Agama Islam. Sementara jika para orang tua siswa yang hendak memilihkan bahan bacaan pada anaknya, buku-buku penunjang yang dipilih sangat tergantung pada kecenderungan pemilihan bukuberdasarkan petunjuk dari tokoh-tokoh agama dan orang-orang tua. Meski pada kenyataannya buku-buku itu tidak terlalu banyak diminati oleh siswa sekolah dasar kecuali cerita-cerita nabi dan buku-buku agama bergambar yang beredar di toko-toko buku. "Sebenarnya kita orang tua murid sudah berusaha mendukung menyediakan buku-buku agama di rumah, selain yang dipakai di sekolah, tapi kelihatannya anakanak lebih cenderung mendahulukan bukubuku sekolahnya karena mungkin berhubungan langsung dengan ujiannya nanti". (Wawancara dengan Herawati Nur, Orang Tua Murid).

Konteks pengadaan buku PAI juga sangat berkaitan erat dengan kultur yang telah berlaku di sekolah sasaran, meskipun tetap melakukan penyesuaianpenyesuaian khusus sebagai respon atas kebijakan yang dikeluarkan dinas yang berwenang. "Sebenarnya, kalau kita bicara tentang bagaimana buku pelajaran itu bisa sampai ke tangan kami para guru lebih banyak menerima bantuan dari Dinas Pendidikan Kota Balikpapan, khususnya tempo hari buku-buku terbaru sesuai kurikulum 2013. Jadi apa yang diberikan itu yang coba kami implementasi, meskipun jumlahnya terbatas, sehingga kita siasati dengan penyesuaian-penyesuaian. Selain itu, juga kita memanfaatkan dana Bos Daerah Kaltim yang Palokasinya berbeda dengan dana BOS pusat, sehingga kita bisa melakukan kebijakan-kebijakan dengan terlebih dahulu dirapatkan". (Abdul Halim, Guru PAI SDN-004 Balikpapan Utara). Akan tetapi, tidak jarang diantara para guru dan orang tua murid ada yang memiliki tingkat kepekaan tinggi dalam melihat arti penting buku sebagai sarana utama dalam proses pendidikan formal di sekolah. Kepekaan itu bisa karena kemampuan ekonomi yang mumpuni, atau latar belakang pendidikan tinggi, persambungan informasi, serta kondisi lingkungan yang mendukung sehingga mereka secara adaptif bisa menyesuaikan kebutuhan buku bagi siswa dan anakanaknya sesuai perkembangan zaman. "Updating buku-buku terbaru itu bisa kami peroleh antara lain dengan komunikasi aktif dengan rekan-rekan sesama guru, serta komite sekolah yang memberi masukan, sehingga kami berusaha mengadakannya dengan inisiatif sendiri mengingat pentingnya buku-buku itu untuk menunjang proses belajar mengajar, bagi orang tua siswa yang memiliki kemampuan ekonomi yang reltif berada juga banyak yang membekali anak-anaknya dengan buku-buku baru, kalau tidak bisa dibeli sendiri, juga banyak yang fotocopy". (Gusti, Guru PAI SDN-013 Balikpapan Barat).

Terkait dengan pola pengadaan buku pelajaran PAI, setidaknya dapat dipetakan menjadi dua kecenderungan sikap dari pihak sekolah, yakni: pertama, bersikap pasif, bahwa dalam rangka menghadirkan buku pelajaran agar bisa digunakan pihak sekolah menunggu penyaluran resmi dari dinas terkait dalam hal ini Dinas Pendidikan Kota Balikpapan, dan atau Kementerian Agama. Selain itu, menunggu kedatangan penerbit untuk menawarkan buku pelajaran juga menjadi bagian sikap pasif sekolah karena pihak penerbitlah yang lebih dominan dan proaktif dalam memberikan informasi dan penawaran buku-buku terbaru. Kepasifan ini juga tercermin dari frekuensi kunjungan pihak penerbit ke sekolah sasaran yang 
tidak terlalu banyak. Sikap pasif ini juga tidak terlepas dari kurangnya informasi yang diperoleh pihak sekolah dalam hal sistem distribusi buku-buku PAI, sehingga kesan menerima apa yang dibagikan masih sangat jelas terlihat. Kecenderungan kedua, bersikap aktif, bahwa dalam rangka menghadirkan buku paket PAI supaya bisa digunakan, pihak sekolah dalam hal ini para guru PAI melakukan inisiatif pencarian informasi dan update buku-buku terbaru melalui survei dan pembelian langsung buku-buku PAI yang dibutuhkan ke tokotoko buku, dan informasi berbasis selancarselancar internet yang telah disediakan di sekolah. Fotocopy dan penggandaan buku juga dilakukan dalam rangka pemenuhan kebutuhan buku untuk pegangan guru dan siswa.

Selain itu, keberadaan BSE (Buku Sekolah Elektronik) melalui downloading langsung buku-buku pelajaran ke situssitus web kementerian pendidikan menjadi bagian yang juga menunjukkan antusias pengadaan buku terbaru. Sikaf aktif lainnya juga dapat dilihat dari saling bagi dan saling tanya antar guru PAI di sekolah lain terkait buku-buku yang ada melalui forumforum diskusi atau komunikasi antar guru secara individual. Keaktifan para orang tua siswa untuk membekali anak-anak mereka dalam hal buku pegangan individual juga sangat menentukan ketersediaan buku, meskipun tidak semua orang tua memiliki kecenderungan yang sama.

Sejauh ini ketersediaan buku di Sekolah Dasar kota Balikpapan lebih banyak melakukan kombinasi dari semua buku yang dikeluarkan oleh penerbit yang datang ke sekolah-sekolah atau melalui gurunya langsung, sehingga para guru dan sekolah menggunakan buku keluaran penerbit yang telah dikenal misalnya Erlangga, Yudisthira, Bumi Aksara, Acarya Media Utama, dan yang lainnya. Tidak kalah pentingnya menjadi sorotan dalam penelitian ini adalah keberadaan dana Bantuan Operasional Sekolah (BOS) daerah yang dialokasikan oleh pemerintah daerah Kota Balikpapan yang sesungguhnya juga menjadi salah satu nilai lebih penyelenggaraan pendidikan yang dapat membantu pengadaan sarana dan prasarana yang dibutuhkan termasuk di dalamnya buku pelajaran. Sejatinya, melalui dana inilah yang dapat dimanfaatkan secara efektif oleh sekolah dalam pemenuhan kebutuhan buku, serta hal-hal teknis lainnya yang dapat menunjang keberlangsungan pembelajaran.

Sementara itu, posisi pengawas PAI juga menjadi bagian penting sebagai alat kontrol bagi sekolah-sekolah di Kota Balikpapan dalam rangka pemenuhan kebutuhan dan kesesuaian buku pelajaran PAI. "Secara umum, proses pengadaan dan distribusi buku PAI ke sekolah-sekolah itu berlangsung dengan baik, sebab para guru dan pihak sekolah sering melibatkan kami para pengawas sebagai dalam rangka meminta pertimbangan-pertimbangan dalam memilih buku mana yang sesuai. Hal itu sangat dimungkinkan karena urung rembug pembuatan soal-soal ujian semseter, maupun ujian sekolah juga melibatkan pengawas dalam forum-forum pertemuan KKG (Kelompok Kerja Guru) yang berlangsung rutin. Sinergitas iniperlu sebab pernah ada buku pelajaran yang dibawa langsung oleh penerbit ke sekolah dimaksudkan untuk dijual dengan mengatasnamakan buku paket kurikulum 2013, tapi setelah dilakukan pengecekan karena kebetulan kami berada di tempat, ternyata buku yang dimaksud itu ternyata hanya sampulnya saja yang ada tulisan 
kurikulum 2013, tetapi isinya masih KTSP. (Wawancara dengan Abdul Halim, Pengawas PAI SD Kemenag Balikpapan).

\section{Mekanisme Pemanfaatan Buku PAI}

Pemanfaatan buku PAI, terkait jumlah dan bagaimana cara memanfaatkannya tidak bisa dilepaskan dari pemilihan kurikulum yang digunakan oleh sekolah. Dikatakan pemilihan, sebab pasca peraturan menteri pendidikan nasional tentang implementasi kurikulum 2013, sesungguhnya memberi ruang kepada sekolah untuk kembali ke kurikulum 2006 jika tidak siap dan demi kepentingan siswa yang lebih besar, meskipun sebelumnya ditunjuk/mengajukan diri sebagai sekolah percontohan kurikulum 2013. Itupun harus dengan sepengetahuan dan persetujuan Dinas Pendidikan setempat. Hal inilah yang dilakukan oleh SDN 004 Balikpapan Utara, yang karena alasan sarana dan prasarana khususnya buku pelajaran yang belum terdistribusi secara total, kemudian memilih untuk kembali mengimplementasikan kurikulum 2006 di sekolahnya. "Sebenarnya sekolah kami sudah terhitung 3 semester menjalankan kurikulum 2013, sebelum adanya edaran yang membolehkkan untuk kembali ke kurikulum 2006. Pada akhirnya kami kemudian memilih untuk kembali mengimplementasikan kurikulum 2006, sebab sarana dan prasaran serta kesiapan secara teknis dan pembimbingan kepada guru belum tuntas dilakukan sehingga dalam pelaksanaannya sangat njilmet (ribet). Apalagi, buku yang kita tunggu-tunggu belum juga didatangkan. Sebelumnya memang pernah ada tapi sangat terbatas, dan tidak sesuai kuota 1:1 persiswa dan guru. Sangat berbeda dengan buku KTSP yang memang sudah tersedia dan mencukupi untuk seluruh siswa dan guru di sekolah kami. (Wawancara dengan Abdul Halim, Wakil Kepala Sekolah SDN 004 Balikpapan Utara, sekaligus sebagai guru PAI).

Pada dasarnya, untuk kurikulum 2006/ KTSP, ketersediaanbukudisekolahdasarKota Balikpapan dianggap sudah cukup. Rasionya pun sudah memenuhi jumlah siswa dan guru, sehingga pemanfaatannya pun hampir tidak memiliki kendala, sebab telah berlangsung beberapa tahun. Secara teknis, buku-buku yang telah ada itu dimanfaatkan semaksimal mungkin oleh siswa pada setiap tingkatan kelas. Umumnya, buku dibagikan setiap tahun kepada masing-masing siswa untuk digunakan dalam proses belajar mengajar. Hanya saja, buku itu diberikan bukan untuk dimiliki tetapi hanya dipinjamkan kepada murid-murid dan dikembalikan pada tahun berikutnya. Tentu saja dengan beberapa aturan yang mengikutinya. Hal ini sekaligus dilakukan untuk menanamkan rasa tanggungjawab kepada siswa terhadap apa yang diamanahkan kepadanya, sebab jika buku yang dipinjamkan itu hilang atau cacat maka tentunya ada konsukensinya.

Mengenai teknis peminjamannya di lapangan juga bermacam-macam. Ada sekolah yang membolehkan siswa membawa buku pulang ke rumah untuk digunakan selama satu tahun, ada pula yang peminjamannya disesuaikan dengan jam pelajaran masing-masing. Jadi buku tetap disimpan di perpustakaan dan tidak boleh dibawa pulang, kecuali jika melalui proses sirkulasi dan peminjaman buku di perpustakaan. Hal ini sangat memungkinkan karena para murid juga sudah dibekali kartu keanggotaan perpustakaan dan sewaktuwaktu bisa meminjam buku untuk dibawa 
pulang. "Peminjaman buku hanya dilakukan jika murid yang melakukan inisiatif untuk meminjamnya ke perpustakaan seperti kalau ada tugas dari guru atau menjelang ujian, sebab kita memberlakukan aturan pemakaian buku pelajaran hanya pada jam sekolah, jadi setiap berganti mata pelajaran, murid yang bertugas (piket) yang mewakili teman-temannya untuk membawa buku dari perpustakaan ke kelas masing-masing. Setiap kelas sudah ada kuota bukunya masing-masing, tapi itu hanya buku KTSP saja, sementara buku kurikulum 2013 tidak memenuhi. (Lestari, Guru PAI SD 004 Balikpapan Utara).

Sementara untuk kurikulum 2013 yang telah sempat diberlakukan sebelumnya, secara teknis pemanfaatan bukunya masih jauh dari ekspektasi. Hal ini disebabkan karena ketersediaan buku yang minim, sehingga ikut mengakibatkan pemanfaatan oleh siswa dan guru yang tidak maksimal. Akan tetapi, buku yang sedikit itu tetap digunakan meskipun hanya bisa dimanfaatkan secara terbatas. Kebanyakan pemanfaatan itu lebih cenderung berbasis inisiasi, seperti fotocopy dan dowloading buku, namun hal tersebut hanya bisa dilakukan oleh mereka yang memiliki kepedulian dan tingkat ekonomi di atas ratarata. Oleh merekayang orang tuanya mampu, pemanfaatan buku dilakukan menggunakan gadget khusus. Hal ini tentunya adalah salah satu alternatif yang sangat efesien, karena buku-buku wajib dan penunjang sudah banyak tersedia di situs kementerian pendidikan nasional berbentuk elektronik book sehingga memungkinkan kepraktisan penggunaannya, meskipun hanya dapat dilakukan jika siswa/murid dibekali gadget semisal komputer tablet, dan smartphone lainnya yang berbasis android.
Hal ini sesungguhnya memiliki nilai positif. Sebab secara bersamaan, akses terhadap informasi penunjang pembelajaran agama Islam lainnya dapat diperoleh setelah melalui pembimbingan tentang cara menggunakannya, namun di sisi lain, aspek pengawasan menjadi sangat penting dalam rangka mengeliminir penyalahgunaan teknologi untuk hal-hal yang tidak diinginkan. "Saya melihat ada anak-anak yang ketika kurikulum 2013 ini diimplementasikan tempo hari, dibekali dengan komputer tablet oleh orang tuanya, dan itu kami tidak larang sepanjang memang digunakan untuk media penyimpanan dan membaca bukubuku elektronik yang sudah dengan mudah di download secara gratis. Tapi kadangkala yang meyulitkan kami para guru, dan tentunya juga harus bisa diperhatikan baik-baik oleh orang tua murid adalah bagaimana supaya alat itu tidak disalahgunakan. Kalau perlu, untuk anakanak setingkat sekolah dasar, cukup bukunya saja yang disiapkan untuk disimpan dalam media penyimpanan smartphone itu, tapi paket internetnya tidak usah diaktifkan. Meskipun di sekolah akses wifi sudah disiapkan, tapi paling tidak situs-situs tertentu sudah dilakukan pemblokiran oleh tim IT kami di sekolah". (Abdul Halim, Wakil Kepala Sekolah/Guru PAI SD 004 Balikpapan Utara).

Namun demikian, hal tersebut tentunya tidak bisa digeneralisasi untuk seluruh siswa di Kota Balikpapan. Sebab tidak semua dari mereka yang memiliki kemampuan untuk mengakses buku-buku elektronik itu. Bahkan jika pun mampu belum tentu punya inisiasi untuk melakukannya. Sehingga pada akhirnya, pemanfaatan buku manual berbasis "apa adanya" atau apa yang tersedia di sekolah masih dominan mewarnai proses pemanfaatan sumber belajar di 
Kota Balikpapan. Namun karena sampai implementasi kurikulum 2013 itu kemudian dipertimbangkan keberlanjutannya, bahkan sampai sekarang, buku-buku itu tidak kunjung datang sehingga membuat sekolah memutuskan untuk kembali ke kurikulum 2006/KTSP, sebagaimana telah dibahas sebelumnya.

Selain itu, di Kota Balikpapan masih banyak diterapkan pelaksanaan pembelajaran Pendidikan Agama Islam dengan menggunakan LKS (Lembar Kerja Siswa). Hal ini adalah perluasan pemanfaatan sumber belajar selain dari buku wajib yang telah tersedia di sekolah, yang bagi guru dikategorikan sebagai buku penunjang. Meskipun pada beberapa tempat, sistem ini sudah ditinggalkan, namun di Kota Balikpapan masih tetap digunakan. Menurut Sungkono, model pembelajaran seperti ini pada dasarnya dinialai masih menggunakan sistem belajar secara individual. Namun dapat pula digunakan pada sistem pembelajaran klasikal. Jika pembelajaran bersifat individual maka siswa akan belajar dari LKS satu ke LKS berikutnya sesuai dengan kecepatannya masing-masing. Mengingat kecepatan masing-masing siswa tidak sama, maka dalam perjalanan belajarnya dari hari ke hari, jarak antara siswa yang pandai dengan siswa yang lamban makin lama makin besar. Teknik ini akan mudah bila di suatu kelas siswanya sedikit. Namun jika jumlah siswa dalam suatu kelas jumlahnya banyak, dan juga mata pelajaran yang dipelajarinya jumlahnya banyak, maka pelaksanaan pembelajarannya menjadi lebih rumit. Pembelajaran dengan sistem modul jika diterapkan untuk pembelajaran secara klasikal maka siswa akan belajar dalam waktu bersamaan dan untuk melanjutkan ke modul berikutnya juga dapat bersamaan. Kepada siswa-siswa yang selesainya lebih cepat dari pada teman-temannya, maka siswa tersebut akan memperoleh modul pengayaan untuk dipelajarinya dalam sisa waktu yang tersedia. Kemudian setelah itu dilakukan evaluasi yang dapat dikerjakan secara individual maupun secara klasikal.

Meski demikian, mekanisme pemanfaatan bahan ajar/sumber belajar di sekolah-sekolah di Kota Balikpapan tidak hanya melulu mengandalkan buku, meskipun buku adalah instrumen utamanya. Penggunaan perangkat pendukung pembelajaran seperti poster, video (audio visual), praktikum, buku cerita, dan alat bantu lainnya tetap digunakan sebagai penunjang pembelajaran pendidikan agama agar lebih bersifat praktikal dan operasional. Meski demikian, buku tetap difungsikan dan selalu ada dalam setiap prosesnya. Seperti misalnya, praktikum Pendidikan Agama Islam lainnya seperti praktek shalat dzuhur, dan shalat dhuha berjamaah yang rutin dilakukan, sesungguhnya tetap menggunakan buku sebagai instrumen penting dalam memuat bacaan-bacaannya. Hal ini juga yang digunakan oleh guru PAI untuk memberikan pemahaman utuh kepada peserta didik. Meskipun sejauh ini metode penyampaian alat pendukung ini sudah semakin berkembang, namun buku-buku penunjang Pendidikan Agama Islam tetap digunakan. Al-Qur'an tetap jadi utama, sebab unsur yang ingin dicapai tidak hanya sekadar kemampuan peserta didik dalam tataran operasional ibadah, tetapi juga memuat unsur baca dan tulis. Di sinilah buku-buku bacaan menjadi dan akan selalu menjadi penting untuk diadakan, dan mengajak para generasi muda untuk mahir 
baca tulis al-Qur'an tetap harus digalakkan. Hal inilah yang menginspirasi pemerintah Kota Balikpapan untuk menggiatkan pemahaman keagamaan generasi muda melalui gerakan Balikpapan Madani (gerakan wajib membaca al-Qur'an), yang diejawantahkan dalam prasyarat utama untuk memasuki jenjang pendidikan yang lebih tinggi (SMP) dimana semua siswa harus memiliki surat keterangan lulus mengaji dari SD-nya.

Kegiatan ekstrakurikuler dan kegiatan kerohanian lainnya adalah wadah lain untuk memanfaatkan dan meningkatkan hasil bacaan para murid, baik dari bukubuku yang diajarkan di sekolah, maupun buku-buku penunjang lainnya. Melalui wadah inilah para siswa dituntut untuk memiliki pemahaman dan pengetahuan yang mendalam, bahkan melebihi apa yang diterima secara reguler di sekolah. Kegiatan kstrakurikuler (pesantren kilat, perkemahan ROHIS, jumat ibadah, peringatan hari besar Islam, bubur asyura'), dan kegiatan kerohanian semacam perlombaan PAI mulai tingkat kelurahan, kecamatan, kabupaten, sampai tingkat propinsi yang digagas oleh Pemerintah Daerah Kalimantan Timur adalah wujud implementasi langsung dari pelaksanaan pendidikan agama Islam. Tentu saja, untuk bisa berbuat banyak pada ajang-ajang lomba semacam itu, diperlukan banyak membaca buku-buku agama Islam. "Perlombaan rutin dan kegiatan ekstrakurikuler bernuansa agama Islam cukup banyak membantu dalam mendorong siswa untuk meningkatkan pengetahuannya melalui buku, dan media lainnya. Terbukti, di beberapa perlombaan yang diiukuti oleh sisw kami beberapa tahun belakangan, sekolah kami selalu keluar sebagai juara di tingkat kelurahan sampai kecamatan, dan berhak mewakili Kota Balikpapan di tingkat propinsi. Setidaknya, hal ini memicu semangat siswa lainnya untuk juga bisa berprestasi. Hal lain yang menjadi bukti riil dari perwujudan operasinalisasi perluasan pembacaan siswa terhadap buku PAI dapat merangsang siswa menulis secara berkelompok dan menghasilkan karya tulis berupa Kisah-kisah nabi, dan makanan halal dan haram". (Lestari, Guru PAI SDN 004 Balikpapan Utara).

\section{Problem yang Dihadapi dan Strategi yang Diupayakan}

Berkenaan dengan pelaksanaan Pendidikan Agama Islam di sekolah, problem yang dihadapi guru PAI sesungguhnya tidak bisa dipisahkan dari teknis implementasi kurikulum di sekolah-sekolah. Seperti misalnya, dalam hal "penghentian sementara" pemberlakuan kurikulum 2013 di sekolah-sekolah yang baru menerapkan satu semester sejak tahun 2014/2015, serta memberi ruang opsi "pengajuan" penerapan kembali KTSP 2006 bagi sekolah yang telah menerapkan kurikulum 2013 selama 3 semester atau bahkan bagi sekolahyangtelah menjadi piloting, dengan "alasan-alasan" serta "persetujuan" dari Dinas terkait sesuai kewenangannya (Permendiknas nomor 160 tahun 2014).

Dampak langsung yang terjadi di lapangan sesungguhnya bisa dilihat dari polemik di kalangan guru PAI di sekolah, dikarenakan pada kurikulum KTSP 2006 alokasi jam pelajaran Pendidikan Agama Islam hanya 3 jam pelajaran, sehingga jika rombongan belajarnya hanya enam, maka guru PAI hanya bisa merealisasikan 18 jam pelajaran perminggu. Hal ini akan berimplikasi pada problem pemenuhan 
syaratuntuk mendapatkantunjangan profesi (sertifikasi) yang mensyaratkan sekurangkurangnya 24 jam tatap muka dalam satu minggu pada satu atau lebih satuan pendidikan. ${ }^{22}$ Namun demikian, terkait kebijakan jam pelajaran Pendidikan Agama Islam di sekolah pada scope Kalimantan Timur sesungguhnya telah diterbitkan Peraturan Daerah Nomor 03 Tahun 2010 tentang Pengelolaan dan Penyelenggaraan Pendidikan Provinsi Kalimantan Timur. Pada pasal 55 ayat 3 PERDA ini menyebutkan bahwa satuan pendidikan wajib menambah muatan pendidikan agama minimal menjadi 4 (empat) jam pelajaran sesuai kebutuhan berupa tambahan materi, jam pelajaran dan kedalaman materi. Tentang pengalokasian jam pelajaran bagi guru PAI di sekolah sebanyak empat jam pelajaran ini diberlakukan baik bagi sekolah yang kembali ke KTSP maupun yang telah mengimplementasikan kurikulum 2013 (Wawancara dengan Suharto, KASI PAIS Kemenag Balikpapan).

Meski demikian, problem baru ternyata muncul ketika guru PAI yang sekolahnya 'kembali' ke KTSP hendak mengisi aplikasi Data Pokok Pendidikan (DAPODIK) akun Website Padamu Negeri pada kolom jumlah jam pelajaran hanya terdapat pilihan alokasi 3 jam saja. Sehingga walaupun secara faktual guru-guru PAI telah melaksanakan tatap muka 4 jam pelajaran, sesuai amanah PERDA nomor 3 tahun 2010 yang telah diaplikasikan secara menyeluruh di semua kabupaten/

\footnotetext{
${ }^{22}$ Agus Susanto. Problematika Beban Kerja Guru PAI pada Sekolah Dasar. (Makalah tidak diterbitkan, 15 Desember 2014, http://agusagif.blospot. com/2014/12/problematika-beban-kerja-guru-paipada.html?m=1, diakses 31 Maret 2015).
}

kota di Kalimantan Timur. Dengan demikian, jika guru PAI mengajar pada 6 rombel, secara kumulatif berbasis PERDA, sesungguhnya telah memenuhi syarat 24 jam perminggu. Namun secara aplikatif dalam isian aplikasi Data Pokok Pendidikan, untuk sekolah yang menerapkan kembali KTSP, hanya bisa dihitung 3 jam saja, atau secara kumulatif jika guru yang bersangkutan mengajar pada 6 rombel hanya bisa terhitung 18 jam saja.

Hal ini sebagaimana dituturkan oleh salah seorang guru PAI dalam pertemuan KKG Balikpapan Barat: "Problem kami sesungguhnya adalah sinkronisasi PERDA Pendidikan Kalimantan Timur dengan form pengisian aplikasi Data Pokok Pendidikan untuk syarat pengajuan NUPTK guru yang sudah kami coba apply, ternyata hanya bisa dihitung 18 jam saja. Padahal saya sudah mengajar di enam kelas dengan masing-masing jumlah tatap muka sebanyak 4 jam. Jelas, kami dirugikan dalam hal ini, sebab pengabdian kami ternyata tidak terhitung sebagaimana kenyataannya di lapangan. Inilah yang membuat kami kebingungan". (Gusti, Guru PAI SD 013 Balikpapan Barat). Kondisi ini menunjukkan betapa para guru PAI berada dalam kebimbangan dalam hal mengimplementasi kebijakan mana yang harus diikuti, sehingga pada akhirnya inisiatif mix kurikulum dilakukan dalam rangka mengakomodir segala bentuk kebijakan dari stakeholder, meskipun dalam pelaksanaannya dilakukan penyesuaian-penyesuaian tertentu.

Meskipun sarana dan prasarana seringkali dijadikan sebagai 'kambing hitam' maksimalisasi pemanfaatan buku pelajaran PAI, namun pada pelaksanaannya SDM guru PAI juga memiliki pengaruh yang besar. Sebaik dan selengkap apapun distribusi dan keberadaan buku PAI di 
sekolah, tanpa ditunjang oleh kemampuan guru untuk menerjemahkan dan mengimplementasikannya dalam proses pembelajaran, maka tentunya perwujudan capaiannya pun menjadi kurang maksimal. Minimnya diklat, pelatihan dan bimbingan teknis terkait pengembangan sumber daya manusia guru PAI juga dianggap sebagai salah satu kendala utama proses pembelajaran PAI di Kota Balikpapan. Bagi guru yang telah mengikuti bimbingan teknis, diklat, workshop, atau apapun bentuk pengembangan SDM yang diikuti itu, seharusnya juga menularkan ilmunya kepada guru lainnya. "Kita ini kekurangan bimbingan dan pelatihan terkait pengembangan SDM, jika pun ada permintaan utusan, maka kuotanya sedikit, dan belum merata. Kita tentunya akan kesulitan mengimplementasi kebijakan tanpa adanya pengayaan sebelumnya yang bersifat kediklatan ataupun model pengembangan lainnya ( $\mathrm{Hj}$. Salmiah, Guru PAI SDN-004 Balikpapan Utara).

Konstruksiidentifikasiproblem-problem khusus yang menyangkut Pendidikan Agama Islam di sekolah sesungguhnya memiliki wadah rutin dalam bentuk pertemuan bulanan Kelompok Kerja Guru PAI setiap kecamatan yang dilakukan secara bergiliran oleh sekolah-sekolah yang tergabung dalam KKG itu. Hal ini sekaligus dijadikan sebagai media pertukaran gagasan antar guru PAI dalam pelaksanaan pembelajaran PAI seharihari. Kelompok ini juga merupakan tempat sosialisasi kebijakan yang dikeluarkan oleh stakeholder terkait, sehingga segala bentuk persoalan baik teknis maupun operasional dibahas dan ditemukan pemecahannya di forum ini. Model identifikasi problem sampai pencarian solusinya dilakukan secara bottom-up. KKG sekaligus menjadi wadah yang sangat strategis untuk memperbincangkan dan menemukan solusi dari setiap problem yang dihadapi para guru PAI, mulai dari bagaimana menyikapi kebijakan, sampai pada pemilihan buku ajar yang cocok, sebab nantinya akan bersamasama merumuskan soal-soal ujian untuk para siswa. Selebihnya, sebagai guru yang mengajarkan dan menganjurkan Islam kepada para murid, tentunya sikap berserah dan berdoa pasca ikhtiar senantiasa disertakan. "Mimpi, harapan, usaha dan doa selalu kami sertakan dalam setiap langkah kami, dalam setiap aktivitas kami, demi membantu siswa kami mewujudkan cita-cita mereka. Kami hanyalah manusia biasa, kami tidak mampu mewujudkan asa dan harapan semua anak didik kami, meski kami tahu bahwa segitu banyak anak didik kami yang menggantung cita-cita tinggi demi masa depan mereka. Satu hal yang kami tahu pasti, kami tida dapat membawa anak didik kami ke masa depan, tapi kami hanya mampu mengantarkan mereka ke tepi masa depan. Sebab mereka adalah anak zaman yang akan menjadi dirinya sendiri di masa depan. Semoga Tuhan membantu dan membimbing mereka dan senantiasa memberikan ketabahan dan kekuatan bagi kami dalam mewujudkan citacitanya. (Gusti, Guru PAI SDN 013 Balikpapan Barat).

\section{PENUTUP}

Optimalisasi pemanfaatan Buku PAI di Sekolah Dasar sangat bergantung pada ketersediaan buku wajib dan penunjang sebagai manifestasi kebijakan yang dikeluarkan oleh seluruh perangkat pendidikan, mulai dari stakeholder, komponen pendidikan serta dukungan masyarakat. Pemilihan kurikulum juga 
sangat mempengaruhi proses pemanfaatan buku. Sebab faktanya, penyaluran dan distribusi buku kurikulum 2013 belum maksimal, bahkan terdapat sekolah yang memutuskan untuk kembali ke KTSP karena alasan ketersediaan buku paket. Padahal sekolah tersebut adalah salah satu sekolah piloting/percontohan implementasi kurikulum 2013 di Kota Balikpapan. Aspek pengawasan terhadap distribusi juga menjadi penting dalam rangka menopang pencapaian tujuan Pendidikan Agama Islam melalui kesesuaian buku berbasis kebutuhan. Namun secara umum inisiatif guru dan orangtua murid menjadi faktor dominan yang sangat menunjang dalam memaksimalkan pemanfaatan buku sebagai sumber belajar di Kota Balikpapan.

Penelitian ini melahirkan beberapa rekomendasi sebagai acuan rencana tindak lanjut dari penelitian ini, yaitu: (1) Perlu ada jaminan bagi guru dan siswa untuk mengakses buku-buku terbaru sehingga pengadaan buku teks pelajaran PAI perlu mendapat perhatian utama bagi pemerintah untuk kelancaran proses pembelajaran di sekolah. Perhatian terhadap PAI minimal sama dengan mata pelajaran lainnya. Untuk itu, diperlukan peran pengambil kebijakan, dalam hal ini Kementerian Agama, Dinas Pendidikan dan Kebudayaan, serta Kepala Sekolah, agar lebih memperhatikan ketersediaan buku PAI di sekolah hinggga mencapai rasio 1:1.(2) Perlunya peningkatan kompetensi guru berupa pemerataan kesempatan pada guru-guru PAI di daerah untuk mengikuti diklat, bimbingan teknis, serta sosialisasi tentang kurikulum khusus PAI oleh Kementerian Agama maupun Dinas Pendidikan dan Kebudayaan untuk mendorong munculnya inovasi dalam pembelajaran. (3) Penerapan kurikulum perlu mempertimbangkan kemampuan guru, dan juga ketersediaan buku teks. (4) Perlunya optimalisasi peran dan fungsi Kelompok Kerja Guru PAI di setiap daerah. (5) Diperlukan kebijakan dalam hal pemerataan guru PAI di sekolah berdasarkan rasio jumlah rombongan belajar. (6) Diperlukan pengawasan terkait materi buku-buku PAI yang akan diterbitkan dan yang beredar di masyarakat.

\section{UCAPAN TERIMA KASIH}

Penelitian ini dapat terselesaikan atas bantuan banyak pihak. Karenanya, penulis mengucapkan terima kasih yang tak terhingga kepada semua pihak yang telah membantu penelitian ini. Secara khusus, penulis ucapkan terima kasih kepada beberapa informan kunci, yaitu: Suharto (Kepala Seksi PAIS Kementerian Agama Balikpapan), Abdul Halim (Pengawas PAI SD Kementerian Agama Balikpapan), Wakil Kepala Sekolah/Guru PAI SDN 004 Balikpapan Utara), Herawati Nur (orangtua murid), Lestari (guru PAI SDN 004 Balikpapan Utara), Hj. Salmiah (guru PAI SDN 004 Balikpapan Utara), dan Gusti (guru PAI SDN 013 Balikpapan Barat). 


\section{DAFTAR PUSTAKA}

Andrini, Vera Septi (2010): Paradigma Pengembangan Sekolah Unggulan. Education Zone.

As'ad, Muhammad, dkk. (2009): Reformulasi Buku-buku Paket Madrasah. Makassar, Idelenggara.

Badan Standar Nasional Pendidikan (2006): Standar Isi untuk Satuan Pendidikan Dasar dan Menengah. Jakarta.

Cresswell, John W. (1994): Research Design, Qualitative and Quantitative Approaches. California, Thousand Oaks.

Departemen Pendidikan Nasional (2008): Kamus Besar Bahasa Indonesia (Pusat Bahasa) Edisi Keempat. Jakarta, PT. Gramedia Pustaka Utama.

Imran, Syaiful (2014) Fungsi, Tujuan, dan Pemanfaatan Buku Teks dalam Pembelajaran. Sumber: https://www. ilmupendidikan.net.

Irawan, Bambang (2010): Buku adalah Jendela Dunia (Refleksi Hari Buku Nasional 17 Mei). UIN Suska Riau.

Mayusa, Fauziah (2013): Perbandingan antara Cara Belajar Menggunakan Buku dengan Menggunakan Internet terhadap Tingkat Konsentrasi Belajar Siswa. Sumber: https//: www.academia.edu.

McLaughlin, Terry. (tth.): Effective Schools Research And The Role of Professional Learning Communities. Assistant Superintendent, Student Services San Bernardino County Superintendent of Schools.

Milles, M.B. and Huberman, M.A. (1984): Qualitative Data Analysis. London, Sage Publication
Muhaimin (2005): Pengembangan Kurikulum Pendidikan Agama Islam di Sekolah, Madrasah, dan Perguruan Tinggi. Jakarta, PT. RajaGrafindo Persada.

Mulyana, Deddy (2008): Metodologi Penelitian Kualitatif(Paradigma BaruIlmu Komunikasi dan Ilmu Sosial Lainnya). Bandung, PT. Remaja Rosdakarya.

Mulyasa, E. (2008): Standar Kompetensi dan Guru Sertifikasi. Bandung, PT. Remaja Rosda Karya.

Muslim, Abu (2015): Membaca 'Pusat Literasi' dari Pelosok Negeri (Ironi Pengelolaan Perpustakaan Madrasah Aliyah di Konawe Selatan). PENAMAS Jurnal Penelitian Keagamaan dan Kemasyarakatan Balai Litbang Agama Jakarta, Volume 28 Nomor 1, April-Juni 2015.

Nasution (1999): Teknologi Pendidikan. Jakarta, Bumi Aksara.

Nur S., Ahmad (2011): Pengembangan Kurikulum Pendidikan Agama Islam (PAI) di Sekolah Menengah Atas (SMA) (Studi Multikasus di SMA Negeri 2 Lumajang dan SMA Jendral Sudirman Lumajang). Tesis Pada Konsentrasi Pendidikan Agama Islam, Program Pascasarjana UIN Malang.

Prastowo, Andi (2012): Panduan Kreatif Membuat Bahan Ajar Inovatif. Jogjakarta, DIVA Press.

Pringgawidagda, Suwarna (2002): Strategi Penguasaan Berbahasa. Yogyakarta, Adicita.

Sudjana, Nana dan Ahmad Rivai (2007): Teknologi Pengajaran. Bandung, Sinar Baru Algesindo.

Sugiyono (2010): Metode Penelitian Pendidikan (Pendekatan Kualitatif, Kuantitatif, dan $R \& D)$. Bandung, Alfabeta. 
Sungkono dkk. 2003. Pengembangan Bahan Ajar. Yogyakarta: Fakultas Ilmu Pendidikan Universitas Negeri Yogyakarta.

Supriadi, Dedi (2000): Anatomi Buku Sekolah di Indonesia; Problematika Penilaian, Penyebaran, dan Penggunaan Buku Pelajaran, Buku Bacaan dan Buku Sumber. Yogyakarta, Adicita Karya Nusa

Susanto, Agus (2014): Problematika Beban Kerja Guru PAI pada Sekolah Dasar. (Makalah tidak diterbitkan, 15 Desember 2014. Dikutip dari http://agusagif.blospot. com/2014/12/problematika-bebankerja-guru-pai-pada.html?m=1, diakses 31 Maret 2015).

Tarigan, H. G. (1986): Telaah Buku Teks Bahasa Indonesia. Bandung, PT. Angkasa.

Warsita, B. (2008): Teknologi Pembelajaran. Jakarta, PT. Rineka Cipta.

Yunanto, S.J. (2004): Sumber Belajar Anak Cerdas. Jakarta, PT Grafindo.

\section{Regulasi}

Undang-Undang Sistem Pendidikan Nasional Nomor 20 Tahun 2003.

Peraturan Pemerintah Nomor 32 Tahun 2013 tentang Perubahan Atas Peraturan Pemerintah Nomor 19 Tahun 2005 tentang Standar Nasional Pendidikan.

Permendiknas No. 22 Tahun 2006 tentang Standar Isi.
Permendiknas No. 23 Tahun 2006 tentang Standar Kompetensi Lulusan.

Permendiknas No. 24 Tahun 2006 tentang pelaksanaan Permendiknas Nomor 22 dan 23.

Permendikbud Nomor 71 tahun 2013 tentang Tentang Buku Teks Pelajaran dan Buku Panduan untuk Pendidikan Dasar dan Menengah.

Peraturan Menteri Pendidikan Nasional Republik Indonesia (Permendiknas) Nomor 11 Tahun 2005 tentang Fungsi, Pemilihan, Masa Pakai, Kepemilikan, Pengadaan, dan Pengawasan Pengunaan Buku Teks Pelajaran.

Peraturan Menteri Pendidikan Nasional Republik Indonesia Nomor 2 Tahun 2008 Tentang Buku.

\section{Daftar Informan}

Suharto (Kepala Seksi PAIS Kementerian Agama Balikpapan).

Abdul Halim (Pengawas PAI SD Kementerian Agama Balikpapan).

Abdul Halim (Wakil Kepala Sekolah/Guru PAI SDN 004 Balikpapan Utara).

Herawati Nur (Orang Tua Murid).

Lestari (Guru PAI SDN 004 Balikpapan Utara).

Hj. Salmiah (Guru PAI SDN 004 Balikpapan Utara).

Gusti (Guru PAI SDN 013 Balikpapan Barat). 